\title{
Emerging Multinationals: Outward FDI from the BRICS countries
}

\author{
Peter Gammeltoft, Ph.D. \\ Associate Professor \\ Department of International Economics \& Management \\ Copenhagen Business School \\ Porcelænshaven 24; DK-2000 Frederiksberg; Denmark \\ Phone: +45 38153369 Fax: +45 38152500 \\ Email: pg.int@cbs.dk
}

July 2007

\section{Introduction}

South Korean and Taiwanese brands have long been household names. Today, however, the names of transnational companies (TNCs) from an increasingly diverse set of emerging and developing economies are regularly making if not the dinner table conversation then at least the headlines of the international business press. This reflects that companies such as Mittal and Tata (India), China National Offshore Oil Corporation (CNOOC), Haier and Lenovo (PRC), Embraer (Brazil), SAPMiller (South Africa), and Cemex (Mexico) are foraying ever deeper into the international economy and increasingly investing abroad.

Even though FDI usually constitutes only a minor part of countries' total capital formation, the relationships between FDI and economic growth, welfare, and industrial upgrading in developing countries have been the object of long and extensive treatment in the literature. However, the literature has overwhelmingly focused on the impact of outward FDI from developed countries into recipient developing countries. Much less analyzed has been the increasingly important phenomenon of outward FDI (OFDI) from the developing countries themselves, be it into developed or into other developing countries. Apart from a few early pioneering studies (Lecraw 1977; Lall 1983; Wells 1983; Agarwal 1985) only few studies have been made so far of outward investment from emerging and developing economies. This is in spite of the fact that the value of outward FDI stock from developing countries reached USD859 billion in 2003, up from USD129 billion in 1990, and has increased 11 times since 1985.

A limited number of recent studies do exist, though (e.g. Cai 1999; Lecraw 1993; van Hoesel 1999; Tolentino 1993; Andreff 2003; Chudnovsky and López 2000; Bulatov 1998, Yeung 2000). Furthermore, academic interest in the subject picked up considerably with the publication of UNCTAD's 2006 World Investment Report, which was dedicated to the subject of FDI from developing and transition economies. The report was succeeded by a number of journal special issues (e.g. JIBS 2007, JIM forthcoming, TC forthcoming) and books (e.g. Goldstein 2007; Benito and Narula 2007).

This paper takes stock of the mounting trend of outward FDI from emerging economies, with special focus on a group of five countries, which are becoming increasingly economically and politically influential, viz. the 'BRICS' countries. An ' $S$ ' is appended here to the conventional acronym of 'BRIC' (Brazil, Russia, India, China) to include the largest economy on the African continent, South Africa. The five BRICS countries produced some USD25 billion of outward FDI flows in 2004, corresponding to some 3 percent of world FDI flows and well over half (61 percent) 
of total developing country outflows. OFDI from the BRICS countries has grown rapidly over the last few years, while still remaining modest compared to many developed countries.

Following a brief discussion of FDI and emerging economies in general the article proceeds to hypothesise that the increase we currently observe in outward investment from emerging and developing economies may constitute a third 'wave' of OFDI, distinct from the two previous waves depicted in the literature, and outlines the contours of such a wave. An empirical analysis OFDI from the BRICS countries follows, conducted at three levels: global (what is the extent, directions, etc. of outward FDI); sectoral (in which sectors is outward FDI significant); and firm level, identifying a small number of particularly interesting TNCs from emerging and developing economies.

\section{FDI and emerging economies}

While the impact of FDI on host economies remains an important topic of scholarly attention, the policy position has generally shifted from being more sceptical in the 1970s enforcing a range of conditionalities on FDI, which in turn influenced firm-level internationalisation patterns and strategies, to a much more accommodating position from the 1990s onwards. These latter policies emphasised investment promotion and the provision of the best possible framework conditions for foreign investors, including infrastructure provision, fast track bureaucratic procedures, and different forms of subsidy and tax alleviation schemes. Interestingly, today OECD countries have begun to deliberate policies to provide those same kinds of incentives to TNCs from emerging and developing economies contemplating outward investment into the OECD.

According to standard economic theory FDI inflows to a developing country increase its capital stock and raises the host country's labour productivity, output, employment, and incomes (Blomström et al. 1996). In addition to these direct effects the literature suggests that further efficiency gains in the host economy accrue from the increased competition and discipline generated by foreign firms, from technological and managerial spillovers, and from learning-bydoing effects in local suppliers (De Mello Jr. 1997; Huang 2004; Hirschman 1958). The financial flows involved are usually considered of secondary in importance to the transmission of ideas and technological, organisational, and business knowledge. This transmission takes place through the FDI operations; the production, employment, capital investment, and R\&D of multinational firms. It takes place horizontally within industries where multinational firms operate and vertically across industries to supplier and customer industries, and from industries to consumers (Lipsey 2005). Export-oriented FDI by TNCs may also promote exports and economic growth by the establishment of assembly plants and by providing host country firms access to international markets for exports (Aitken and Harrison 1997; De Mello Jr. 1997; Zhang 2001).

Most contemporary analyses and national development strategies tend to emphasise the positive potentials inherent in FDI and the East Asian countries' successful combination of foreign technology transfers with export marketing have translated into a general case for strategies attempting to tap into foreign sources of technology (see for instance Wade 1995 and Lall 1995). ${ }^{1}$ But the positive assessment is not unanimous and many debates remain unsettled. Some studies (Chakraborty and Basu 2002; De Mello Jr. 1997) suggest that the causality does not run from FDI

\footnotetext{
${ }^{1}$ Different countries and regions have been able to benefit from FDI to very different extents, though. Southeast Asian models have been characterized as 'technology-less' (Yoshihara) as opposed to Northeast Asia's more activist exploitation of the combination of foreign investment, local technology absorption and export marketing. Even though China appears to be experimenting with implementing several different of the Asian development models at the same time (Dodgson), China has generally vigorously pursued technology transfer agreements in exchange for market access in connection with inward foreign investment.
} 
to GDP growth but rather in the opposite direction, from GDP to FDI, reflecting that FDI is often of the market-seeking variety (Dunning 1988) and attracted by growing local markets for services such as retail, telecommunications, and financial services (Mortimore 2004). FDI flows may even have negative effects on growth if TNCs apply technologies which do not accord with the host country's factor endowments (e.g. too capital intensive), apply overly-sophisticated techniques and equipment that impede significant transfers from occurring, retain the most advanced segments of the valuechain and the most advanced product lines in their home country, do not conduct R\&D locally, perform substantial reverse transfers of remittances of profits and dividends, obtain excessive tax or other concessions from the host country, or require overly restrictive protection of and/or royalty/fee payments for their proprietary technology (cf. the recent Chinese case of prohibitive license fees for DVD decoder chip technology). Other occasionally voiced cautions are that FDI may worsen income distribution, increase 'urban bias', or squeeze local entrepreneurs out of the most dynamic sectors (see for instance Moran 1978; Doner 1991; Singer 1975).

Finally there are studies which suggest that the impact of FDI on growth is contingent on other factors such as whether the country adopts an open trade regime (Balasubramanyam et al. 1996; Ram and Zhang 2002) or a diversity of other factors such as educational attainment, political stability, or the state of the financial system (UNCTAD 1999). What such contingencies are concerned, increasing attention is being paid to the issue of 'absorptive capacity' (Cohen and Levinthal 1990). A growing literature suggests that the variations in growth effects of FDI can to a large part be explained by differences in the abilities on the receiving end to absorb the knowledge and technological potentials FDI provides (Keller 1996; Borensztein et al. 1998; Durham 2004; Olofsdotter 1998). Basically, the level of human capital development in the economy along with deliberate investments in learning-enhancing training and $R \& D$ at the firm level determines the ability to benefit from FDI. An interesting recent contribution to this line of argument has been made by Martin Bell and associates, arguing that spillovers are neither an automatic process inherent to FDI nor predominantly determined by the passive and incidental 'absorptive capacities' of local firms. Rather it is contingent on active efforts towards 'technological accumulation' on behalf of local firms and deliberate forging of linkages between foreign investors and local firms (Bell and Marin 2004).

A strand of the general literature on FDI is particularly relevant to outward FDI from emerging/developing economies: Findlay (1978) argued that the extent to which spillovers will accrue from FDI depends on the difference in the level of technological complexity, or the 'technology gap', between multinationals and local firms: the larger the difference, the larger the potential for spillovers. However, the opposite assumption is equally reasonable: gaps could be too large and technology and routines deployed by TNCs too remote from the host economy for any significant spillovers to occur (Taki 2005; Girma et al. 2001). If the latter is true South-South FDI may in this respect offer better developmental potentials than North-South FDI by applying more 'appropriate' technologies, business models, and managerial and organisational techniques, which are better attuned to developing-economy circumstances.

A confluence of factors, such as increasing wealth, trade and investment policy reforms, regional integration, loosening capital controls, progressing industrialisation, and build-up of firm-specific advantages of capabilities have led many developing countries to become a significant source of FDI, particularly to other developing countries (Battat \& Aykut 2005). Since developing countries are typically scarce on capital and abundant on labour and faced with foreign exchange shortages there would be immediate economic arguments against engaging in large scale capital export, focusing instead on capital import. However, not least in order to build and maintain firm-level competitiveness, today many developing and emerging economy governments actively support the 
internationalization of domestic firms through a range of supportive policies, especially in large emerging economies (Sauvant 2005; UNCTAD 2005b).

Firms such as Daewoo, Hyundai and Samsung (Korea), Petrobras and Embraer (Brazil), Acer and Tatung (Taiwan) have become fully-fledged TNCs today. While TNCs flurry to China attracted by factor costs and market potentials, China's own multinationals have begun to tap into even cheaper labour elsewhere. They are investing in bicycle production in Ghana and video players in SouthEast Asia. Ramatex, a Malaysian textile firm, has built a plant in Namibia, from which it serves the world's garment market (Economist 2005). Conventional wisdom holds that companies such as these from developing and emerging economies are significantly disadvantaged when trying to expand internationally. However, experiences from their home economy can provide a valuable springboard rather than a disadvantage: they are accustomed to demanding and price-sensitive customers and challenging distribution environments and this can enable them to develop the capabilities they need to also compete successfully elsewhere (Sinha 2005). In poor countries in specific, developing-country multinationals often do better than their developed-country rivals. While they are not as cash rich, they can operate with lower overheads, and while their technology may be less advanced, it is better suited to the countries in which they invest. They are also often closer to the host country, both geographically and culturally, and tend to be more accustomed to the risks of investing in countries with unpredictable political and regulatory environments and lessstable economies (Economist 2005; Aykut and Ratha 2004).

\section{A third wave of OFDI?}

Many TNCs from emerging and developing economies (ETNCs) have gradually accumulated technological capabilities and firm specific advantages sufficient to expand their operations to other countries and flows of outward investment from emerging and developing economies have consequently increased significantly in quantitative terms. In addition however, when probing beneath the quantitative surface a number of important qualitative changes in the composition and structural characteristics of outward investment from the developing world are revealed. This becomes apparent when comparing the older and the newer literature on OFDI. Previously, up into the 1980s, emerging economy firms mainly invested abroad to establish trade supporting networks and to access markets. Access to natural resources abroad and escape from bureaucratic restrictions at home were other prominent motives. Investments were mainly in other developing countries, especially those with short psychic distance (geographic, cultural, ethnic, institutional). ETNCs typically entered with minority ownership and engaged in greenfield investments and in many countries the companies most active in outward investment were state owned. When investing in developed economies they were mainly active in 'sunset' industries with less fierce competition from developed country counterparts.

From the 1990s onwards there were various shifts in the investment motives, modes of ownership, sectoral composition and typical destinations of OFDI (see also Pradhan and Liu in this volume): ETNCs were more frequently privately owned, even though a high degree of state ownership remains among the largest ETNCs, especially in natural resources. They more frequently took on majority ownership in outward investment projects and even though greenfield investments remain the dominant entry mode, international acquisitions became more frequent. Services became the dominant sector in OFDI (e.g. finance and business services) over manufacturing and natural resources. Even though the developing world remains the main destination of OFDI, investments became increasingly oriented towards developed rather than developing country destinations: reflecting also the cumulative increase in monopolistic advantages of ETNCs they increasingly invested to acquire technology, brands, and marketing capabilities in advanced economies. While a small number of countries remain responsible for the bulk of OFDI, there has also been a 
diversification in terms of the number of emerging and developing economies engaging in outward investments on a larger scale. Access to markets remains the dominant motive, especially where regional and South-South investments are concerned and efficiency seeking is the second most important motive (UNCTAD 2006) but asset-seeking investments into developed economies became gradually important for the purpose of accessing technology, $R \& D$ and marketing capabilities, brands, distribution networks, and managerial and organizational competencies

More generally and for analytical purposes, trends in outward investment from emerging and developing economies can be divided into three broad 'waves'. Any such abstraction and division of time periods into discrete waves must necessarily be rather crude given the inherent national, industry and firm-level diversity in investment projects and flows. There are also many well-known limitations and inaccuracies associated with official FDI statistics: misclassification of capital flight and portfolio flows, misclassification of indirect outward investment by foreign affiliates, and other reporting and registration problems abound, and the problems are especially severe in developingcountry statistics. For these reasons the third wave of OFDI proposed in the following table is put forward as an informed hypothesis, pending closer empirical scrutiny, even though there does seem to be a sufficient extent of deviation from the received literature to propose a third and qualitative different 'wave'.

The investment development path framework (IDP), first put forward by John Dunning, suggests that ETNCs tend to initially invest in resource- and market-seeking activities in neighbouring or other developing countries, and then expand their presence worldwide (Aykut \& Ratha 2004). The received literature suggests that there have been two different waves of outward FDI from developing countries (Dunning et al. 1996, 1998; UNCTAD 2005c): from the 1960s until early 1980s, and thereafter. The first-wave firms were driven mainly by market- and efficiency-seeking factors and investments were mainly directed towards other developing countries, most often neighbouring countries. In the second wave, driven by a combination of pull and push factors, strategic-asset seeking also became a motive and investments into developed countries and developing countries outside the investor's own region became more important. The first wave of FDI originated predominantly from Latin America where new TNCs emerged from Argentina, Mexico and Chile, followed by Brazilian, Colombian and Venezuelan competitors (Andreff 1987). During a period which otherwise emphasized industrialization strategies based on import substitution, Latin American TNCs internationalised on the basis of products that had met the needs of their growing domestic markets and outward FDI went primarily to neighbouring developing countries with similar demand structures. The second stage from the 1980s was dominated by Asian TNCs, spreading from Republic of Korea, Taiwan, Hong Kong, Singapore and thereafter Malaysia, Thailand, China, India and the Philippines, and accompanied Asian countries' export oriented industrialization strategies. Outward FDI from Latin America was less prominent during this period. Asian TNCs expanded mostly in the fast growing foreign markets of other NIEs but they also outward invested to access cheap labour in developing countries that were less developed than their home countries.

Based on a recovery of Latin American outward FDI in the 1990s in the context of global competition in manufacturing and services, Chudnovsky and Lopez (2000) and Andreff (2003) proposes the emergence of a third wave of OFDI. At this stage the largest Asian TNCs already competed with Western TNCs, invested into developed countries, and some countries were becoming net FDI exporters (South Korea, Hong Kong, Taiwan), a position traditionally reserved for developed countries (Andreff 2003). However, the third wave suggested by Chudnovsky, Lopez, and Andreff is mainly generalizing from and focusing on outward investments from Latin America. We propose here the emergence of a different and more general third wave of OFDI. Based on the BRICS-based contributions in this special issue as well as other available evidence, the deviations 
from the two previous waves described in the literature appear to be sufficiently significant to suggest the emergence of a third wave, which is not confined to Latin America but applies to outward investment flows from emerging and developing countries in general. The three waves are summarised in Table 1. Each wave retains most of the features from the previous one but some features are added and others revised. It is also important to note that the waves are broad, 'ideal typical', and aggregate abstractions. At present time for example, any individual developing economy or any individual ETNC may well predominantly exhibit the features of one of the two previous waves.

Table 1 Three waves of outward FDI

\begin{tabular}{|c|c|c|c|}
\hline & First & Second & Third \\
\hline Period & 1960s to mid-1980s & Mid-1980s to 1990 s & 1990 s to 2000 s \\
\hline $\begin{array}{l}\text { Outward investing } \\
\text { region/country } \\
\text { group }\end{array}$ & Especially Latin America & Especially Asia & $\begin{array}{l}\text { More geographically diverse } \\
\text { country origins } \\
\text { Resurgence of Latin America } \\
\text { Inclusion of Russia and South } \\
\text { Africa }\end{array}$ \\
\hline $\begin{array}{l}\text { Country examples, } \\
\text { largest outward } \\
\text { investors }\end{array}$ & $\begin{array}{l}\text { Brazil, Argentina, Singapore, } \\
\text { Malaysia, Venezuela, } \\
\text { Philippines, Hong Kong, } \\
\text { Korea, Colombia, Mexico, } \\
\text { India }\end{array}$ & $\begin{array}{l}\text { Hong Kong, China, Taiwan, } \\
\text { Singapore, South Korea, Brazil, } \\
\text { Malaysia }\end{array}$ & $\begin{array}{l}\text { Hong Kong, Taiwan, Singapore, } \\
\text { Brazil, South Africa, China, } \\
\text { Korea, Malaysia, Argentina, } \\
\text { Russia, Chile, Mexico }\end{array}$ \\
\hline Destinations & $\begin{array}{l}\text { Mainly other developing } \\
\text { countries in same region }\end{array}$ & $\begin{array}{l}\text { Mainly developing countries, but } \\
\text { also to more distant locations, } \\
\text { including developed economies }\end{array}$ & $\begin{array}{l}\text { Increasingly global } \\
\text { (Knowledge-intensive) services } \\
\text { mainly regional destinations } \\
\text { Mature sectors increasingly } \\
\text { also into developed economies }\end{array}$ \\
\hline \multirow[t]{2}{*}{$\begin{array}{l}\text { Types of outward } \\
\text { FDI }\end{array}$} & $\begin{array}{l}\text { Primary sector } \\
\text { Small-scale manufacturing }\end{array}$ & $\begin{array}{l}\text { Into developing: primary sector, } \\
\text { difficult-to-trade services } \\
\text { (finance, infrastructure) } \\
\text { Into developed: mature, cost- } \\
\text { competitive industries } \\
\text { (automotives, electronics, IT } \\
\text { services), asset-augmenting } \\
\text { investments }\end{array}$ & $\begin{array}{l}\text { As } 2^{\text {nd }} \text { wave, but with more } \\
\text { going into developed } \\
\text { economies }\end{array}$ \\
\hline & Mainly horizontal & Horizontal and vertical & Horizonal and vertical \\
\hline \multirow{2}{*}{$\begin{array}{l}\text { Ownership } \\
\text { advantages }\end{array}$} & Home country specific & Home country and firm specific & Home country and firm specific \\
\hline & $\begin{array}{l}\text { Low cost inputs } \\
\text { Production process capabilities } \\
\text { Networks and relationships } \\
\text { (e.g. ethnic) } \\
\text { Organizational structure (e.g. } \\
\text { conglomerates) } \\
\text { 'Appropriate' technology, } \\
\text { business models, and } \\
\text { management }\end{array}$ & Same as $1^{\text {st }}$ wave & $\begin{array}{l}\text { Now also: } \\
\text { Economies of scale } \\
\text { Technological, managerial, and } \\
\text { organizational capabilities } \\
\text { Vertical control over } \\
\text { factor/product markets }\end{array}$ \\
\hline \multirow[t]{2}{*}{ Motivation } & Resource and market seeking & $\begin{array}{l}\text { Into developing: resource and } \\
\text { market seeking } \\
\text { Into developed: market and } \\
\text { asset seeking }\end{array}$ & $\begin{array}{l}\text { As } 2^{\text {nd }} \text { wave, but increase in } \\
\text { asset seeking }\end{array}$ \\
\hline & Asset exploitation & $\begin{array}{l}\text { Asset exploitation } \\
\text { Minor asset augmentation }\end{array}$ & $\begin{array}{l}\text { Also asset augmentation } \\
\text { Market power enhancing } \\
\text { (especially natural resource } \\
\text { related) }\end{array}$ \\
\hline Policy regime & $\begin{array}{l}\text { Import substitution } \\
\text { FDI regulation }\end{array}$ & $\begin{array}{l}\text { Export orientation } \\
\text { FDI coordination and facilitation }\end{array}$ & $\begin{array}{l}\text { Schumpeterian } \\
\text { FDI promotion }\end{array}$ \\
\hline
\end{tabular}

Source: Dunning et al. 1996, 1998, Lall 1983, Chudnovsky and Lopez 2000, Andreff 2003, UNCTAD 2006, plus own revisions and additions, particularly the third wave. 


\section{Outward FDI flows from BRICS}

We return now to the issue of outward investment flows from the BRICS countries in specific. What has been the magnitude of these flows and stocks, in which sectors are they significant, and which are major outward investing firms? The empirical analysis in the following is conducted at three levels: global, sectoral, and firm level.

Table 2 shows the total FDI net outflows from developed (high-income) and developing (low and middle-income) countries, as well as the world total over time. The time series reveals the emergence of multinationals from emerging and developing economies and shows a significant increase in FDI originating from low and middle income countries, from USD797 million in 1980 to USD41,688 million in year 2004. FDI outflows from developing countries as a percentage of world outflows fluctuates but shows an increasing trend throughout the period and reaches $4.8 \%$ of the world total in year 2004.

Table 2 FDI net outflows by country income group, 1980-2004 (current USD mio \& percent)

\begin{tabular}{lrrrrrrrr}
\hline & 1980 & 1985 & 1990 & 1995 & 2000 & 2003 & 2004 & $\begin{array}{c}\text { average } \\
2000-2004\end{array}$ \\
\hline World & 60,856 & 64,272 & 253,432 & 341,182 & $1,361,869$ & 641,576 & 864,205 & 855,580 \\
& $100.0 \%$ & $100.0 \%$ & $100.0 \%$ & $100.0 \%$ & $100.0 \%$ & $100.0 \%$ & $100.0 \%$ & $100.0 \%$ \\
High income & 55,812 & 60,775 & 242,552 & 327,498 & $1,335,997$ & 605,190 & 795,589 & 820,273 \\
& $91.7 \%$ & $94.6 \%$ & $95.7 \%$ & $96.0 \%$ & $98.1 \%$ & $94.3 \%$ & $92.1 \%$ & $95.9 \%$ \\
Middle income & 847 & 1,118 & 2,872 & 11,964 & 16,926 & 25,777 & 36,815 & 21,788 \\
& $1.4 \%$ & $1.7 \%$ & $1.1 \%$ & $3.5 \%$ & $1.2 \%$ & $4.0 \%$ & $4.3 \%$ & $2.7 \%$ \\
Low income & 8 & 17 & 5 & 139 & 647 & 1,694 & - & 1,568 \\
& $0.0 \%$ & $0.0 \%$ & $0.0 \%$ & $0.0 \%$ & $0.0 \%$ & $0.3 \%$ & - & $0.2 \%$ \\
Low \& middle income & $797 *$ & 1,109 & 2,810 & 12,272 & 17,785 & 27,763 & 41,688 & 24,144 \\
& $1.3 \%$ & $1.7 \%$ & $1.1 \%$ & $3.6 \%$ & $1.3 \%$ & $4.3 \%$ & $4.8 \%$ & $3.0 \%$ \\
\hline
\end{tabular}

Source: Calculated from World Bank data, based on International Monetary Fund, International Financial Statistics and Balance of Payments databases.

* 'Low \& middle income' is less than the sum of 'Middle income' and 'Low income' due to inaccuracies in the underlying database.

Table 3 shows FDI outflows from the BRICS countries in specific over the period from 1980 to 2004. There has been a steady increase of total FDI outflow from BRICS over the last decade with the fastest growth in the period from 2002 to 2004. A peak of USD25.4 billion was reached in year 2004; more than three times the total in 2000.

Table 3 FDI net outflows by country, 1980 - 2004 (current USD mio)

\begin{tabular}{|c|c|c|c|c|c|c|c|c|}
\hline & 1980 & 1985 & 1990 & 1995 & 2000 & 2003 & 2004 & $\begin{array}{c}\text { Average } \\
2000-2004\end{array}$ \\
\hline Brazil & 367 & 81 & 665 & 1,384 & 2,282 & 249 & 9,471 & 2,445 \\
\hline Russian Federation & - & - & - & 605 & 3,177 & 9,727 & 10,346 & 5,863 \\
\hline India & - & - & - & 117 & 510 & 1,324 & 2,222 & 1,426 \\
\hline China & - & 629 & 830 & 2,000 & 916 & -152 & 1,805 & 2,394 \\
\hline South Africa & - & 47 & 28 & 2,494 & 277 & 565 & 1,583 & -298 \\
\hline Total BRICS & 367 & 757 & 1,523 & 6,600 & 7,161 & 11,714 & 25,427 & 11,831 \\
\hline Denmark & - & 306 & 1,482 & 2,969 & 28,381 & 856 & $-9,930$ & 7,022 \\
\hline European Monetary Union & 15,229 & 13,482 & 95,456 & 102,849 & 631,975 & 273,444 & 255,958 & 362,973 \\
\hline Germany & 4,690 & 5,786 & 24,483 & 39,100 & 59,744 & $-4,899$ & $-8,101$ & 20,358 \\
\hline Japan & 2,390 & 6,492 & 50,497 & 22,508 & 31,534 & 28,766 & 30,958 & 32,354 \\
\hline United Kingdom & 11,229 & 10,606 & 20,124 & 45,305 & 245,376 & 64,090 & 80,239 & 99,767 \\
\hline United States & 19,230 & 14,060 & 37,200 & 98,780 & 159,212 & 140,580 & 252,013 & 169,722 \\
\hline
\end{tabular}


Brazil was the most important source country for FDI from the Latin American region in 2002, with outflows of USD 2.5 billion. Outflows fell sharply in 2003, reflecting the overall poor performance of the region. In 2004, however, they rebounded sharply placing Brazil among the top five investors in the developing countries (UNCTAD 2004). For Russia, the ratio between outward and inward FDI is considerably higher than any of other CEE countries due to rapid growth in Russian OFDI (UNCTAD 2005a). Indian enterprises have been investing abroad for a long time but even though the total amount of Indian OFDI has increased it remains modest compared to the other BRICS countries. Chinese levels of OFDI were insignificant before 1985. Today the scale of China's OFDI is still small compared with large developed-country outward investors but the trend is upwards and China's peak annual OFDI of USD7 billion in 2001 compares with USD3.5 billion for South Korea and USD1.4 billion for India (UNCTAD 2003b; Liu et al. 2005). South Africa is the single largest source of OFDI from Africa and OFDI has been driven largely by investment in resources as well as by investment opportunities in neighbouring countries as a result of privatizations (UNCTAD 2005c).

As we saw above FDI, in absolute terms outflows from BRICS have increased rapidly over the last few years. We turn next to the question of whether they have also increased in terms of their relative size compared to global FDI outflows and outflows from the developing world.

Table 4 BRICS FDI outflows as percent of world and developing country outflows, 1995-2004 (current USD mio and percent)

\begin{tabular}{|c|c|c|c|c|c|c|c|}
\hline & 1995 & 2000 & 2001 & 2002 & 2003 & 2004 & $\begin{array}{c}\text { average } \\
2000-2004\end{array}$ \\
\hline World & 341,182 & $1,361,869$ & 739,607 & 670,641 & 641,576 & 864,205 & 855,580 \\
\hline Low \& middle income & 12,272 & 17,785 & 15,285 & 18,201 & 27,763 & 41,688 & 24,144 \\
\hline BRICS & 6,600 & 7,161 & 5,042 & 9,809 & 11,714 & 25,427 & 11,831 \\
\hline$\%$ of World & $1.93 \%$ & $0.53 \%$ & $0.68 \%$ & $1.46 \%$ & $1.83 \%$ & $2.94 \%$ & $1.44 \%$ \\
\hline$\%$ of Low \& middle i. & $53.78 \%$ & $40.27 \%$ & $32.99 \%$ & $53.89 \%$ & $42.19 \%$ & $60.99 \%$ & $46.07 \%$ \\
\hline
\end{tabular}

Over the period 2000-2004 FDI outflows from the BRICS countries constituted close to half (46\%) of FDI outflows from developing countries (Table 4), fluctuating between a low of 33\% in 2001 and a high of $61 \%$ in 2004. In other words, in 2004 FDI outflows from BRICS account for well over half of total outflows from developing countries. Relative to world outflows, FDI outflows from BRICS account for an average 1.4\% of the total over the period 2000-2004, with the lowest share being a half percent in year 2000 and the highest 2.9\% in 2004. BRICS outflows as a share of total outflows increased steadily throughout the period, while outflows as a percentage of developing world outflows fluctuate somewhat but displays a clear increasing trend.

Table 5 controls for the different sizes of the BRICS economies and displays FDI outflows as a percentage of GDP. 
Table 5 FDI net outflows by country, 1970-2004 (percent of GDP)

\begin{tabular}{|c|c|c|c|c|c|c|c|c|c|c|c|c|}
\hline & 1970 & 1975 & 1980 & 1985 & 1990 & 1995 & 2000 & 2001 & 2002 & 2003 & 2004 & $\begin{array}{c}\text { average } \\
2000-2004\end{array}$ \\
\hline Brazil & .. & 0.1 & 0.2 & 0.0 & 0.1 & 0.2 & 0.4 & -0.4 & 0.5 & 0.0 & 1.6 & 0.418 \\
\hline $\begin{array}{l}\text { Russian } \\
\text { Federation }\end{array}$ & .. &.. & .. & .. &.. & 0.2 & 1.2 & 0.8 & 1.0 & 2.3 & 1.8 & 1.421 \\
\hline India & .. & 0.0 & 0.0 & 0.0 & 0.0 & 0.0 & 0.1 & 0.3 & 0.3 & 0.2 & .. & 0.191 \\
\hline China & .. & .. & .. & 0.2 & 0.2 & 0.3 & 0.1 & 0.5 & 0.2 & 0.0 & 0.1 & 0.171 \\
\hline South Africa & 0.0 & 0.0 & 0.0 & 0.1 & 0.0 & 1.7 & 0.2 & -3.0 & -0.4 & 0.3 & 0.7 & -0.407 \\
\hline Denmark & .. & 0.2 & 0.0 & 0.5 & 1.1 & 1.6 & 17.9 & 8.3 & 1.5 & 0.4 & -4.1 & 4.811 \\
\hline $\begin{array}{l}\text { European } \\
\text { Monetary Union }\end{array}$ & .. & 0.5 & 0.5 & 0.6 & 1.7 & 1.4 & 10.3 & 5.5 & 4.6 & 3.3 & 2.7 & 5.283 \\
\hline Germany & .. & 0.5 & 0.5 & 0.8 & 1.4 & 1.5 & 3.1 & 2.1 & 0.8 & -0.2 & -0.3 & 1.101 \\
\hline Japan & .. & .. & 0.2 & 0.5 & 1.7 & 0.4 & 0.7 & 0.9 & 0.8 & 0.7 & 0.7 & 0.747 \\
\hline United Kingdom & 1.4 & 1.3 & 2.1 & 2.3 & 2.0 & 4.0 & 17.1 & 4.2 & 3.2 & 3.6 & 3.8 & 6.346 \\
\hline United States & 0.6 & 0.9 & 0.7 & 0.3 & 0.6 & 1.3 & 1.6 & 1.4 & 1.5 & 1.3 & 2.2 & 1.592 \\
\hline
\end{tabular}

Source: Calculated from World Bank data, based on International Monetary Fund, International Financial Statistics and Balance of Payments databases, World Bank, Global Development Finance, and World Bank and OECD GDP estimates.

As the table shows, relative to GDP FDI outflows from the BRICS countries are still modest compared to many developed economies. Among the BRICS countries Russia has the largest FDI outflows relative to GDP, with a peak of 2.3\% in 2003. In terms of the 2000-2004 average, Russia and Brazil are the largest outward investors. South Africa had negative outflows in 2001 and 2002 resulting in negative average 2000-2004.

Turning next to FDI outward stocks rather than flows, the total outward FDI stock from BRICS were USD220 billion in 2004 (Table 6).

Table 6 FDI outward stock by country, 1980 - 2004 (USD mio)

\begin{tabular}{lrrrrrrrr}
\hline & 1980 & \multicolumn{1}{c}{1985} & 1990 & \multicolumn{1}{c}{1995} & 2000 & 2002 & 2003 & 2004 \\
\hline Brazil & 38,545 & 39,439 & 41,044 & 44,474 & 51,946 & 54,423 & 54,892 & 64,363 \\
Russian &.. &.. &.. & 345 & 20,141 & 54,608 & 72,273 & 81,874 \\
Federation & 78 & 93 & 124 & 495 & 1,859 & 4,005 & 5,054 & 6,592 \\
India &.. & 900 & 4,455 & 17,768 & 27,768 & 37,172 & 37,020 & 38,825 \\
China & 5,543 & 8,905 & 15,027 & 23,305 & 32,333 & 21,980 & 27,184 & 28,790 \\
South Africa & & & & 86,386 & 134,047 & 172,188 & 196,423 & 220,444 \\
Total BRICS & & & & & & & & \\
European Union & 212,572 & 302,830 & 805,851 & $1,296,291$ & $3,046,301$ & $3,715,099$ & $4,726,873$ & $5,189,738$ \\
United States & 215,375 & 238,369 & 430,521 & 699,016 & $1,316,247$ & $1,601,414$ & $1,788,911$ & $2,018,205$ \\
Japan & 19,610 & 43,970 & 201,441 & 238,452 & 278,442 & 304,237 & 335,500 & 370,544 \\
United Kingdom & 80,434 & 100,313 & 229,307 & 304,865 & 897,845 & 994,136 & $1,235,898$ & $1,378,130$ \\
Germany & 43,127 & 59,909 & 151,581 & 268,418 & 541,861 & 695,765 & 840,918 & 833,651 \\
Denmark & 2,065 & 1,801 & 7,342 & - & 73,106 & 86,679 & 102,596 & 99,570 \\
\hline
\end{tabular}

Source: UNCTAD, World Investment Report 2005

The largest outward investor in terms of stock is Russia followed by Brazil. India's outward stock is relatively small compared to the other four countries. Total outward stock for BRICS grew by a factor 2.5 from 1995 to 2004.

Outward stock grew particularly quickly for Russia through this period, but also for India and China. The recent statistical updates by the Russian Government confirm previous estimations of large amounts of Russian capital abroad. Unlike in most of the economies in transition, capital outflows from the Russian Federation have repeatedly exceeded capital inflows. Some part of the significant increase in OFDI stock from Russia is attributed to an improved data registering system, 
however. South Africa's OFDI stock of USD29 billion in 2004 accounted for $67 \%$ of the region's OFDI stock (UNCTAD 2005c).

BRICS outward stocks constituted 2.3\% of the world's total stocks in 2004 and $21 \%$ of total from developing countries (see Table 7). Comparing this to the fact that outward flows from BRICS constituted well over half of developing country outflows in 2004 suggests that the significant increase in BRICS outflows is a relatively recent phenomenon.

Table 7 Outward FDI stock by country group, 1980 - 2004 (USD mio and percent)

\begin{tabular}{|c|c|c|c|c|c|c|c|c|}
\hline & 1980 & 1985 & 1990 & 1995 & 2000 & 2002 & 2003 & 2004 \\
\hline World & 570,125 & 752,841 & $1,785,264$ & $2,917,546$ & $6,148,284$ & $7,288,417$ & $8,731,240$ & $9,732,233$ \\
\hline Developed countries & 496,197 & 663,312 & $1,637,760$ & $2,581,190$ & $5,257,261$ & $63,68,560$ & $7,727,178$ & $8,610,146$ \\
\hline Developing countries & 73,927 & 89,529 & 147,313 & 334,720 & 868,920 & 861,568 & 927,442 & $1,035,676$ \\
\hline BRICS & & & & 86,386 & 134,047 & 172,188 & 196,423 & 220,444 \\
\hline$\%$ of World & & & & $2.96 \%$ & $2.18 \%$ & $2.36 \%$ & $2.25 \%$ & $2.27 \%$ \\
\hline$\%$ of Developed & & & & $3.35 \%$ & $2.55 \%$ & $2.70 \%$ & $2.54 \%$ & $2.56 \%$ \\
\hline$\%$ of Developing & & & & $25.81 \%$ & $15.43 \%$ & $19.99 \%$ & $21.18 \%$ & $21.29 \%$ \\
\hline
\end{tabular}

Relative to GDP (see Table 8), Russia was the largest outward investor in 2004, closely followed by South Africa, while the shares of India and China are comparatively small (1.0\% and 2.4\%). As an average over 2000-2004, South Africa was the largest outward investor when seen relative to GDP. South Africa excepted, seen over the period 2000-2004 the BRICS countries' outward stock as a share of GDP is lower than the average for all developing countries. ${ }^{2}$

Table 8 Outward FDI stock as a share GDP, 1980 - 2004 (percent)

\begin{tabular}{lrrrrrrrrr}
\hline & 1980 & 1985 & 1990 & 1995 & 2000 & 2002 & 2003 & 2004 & $\begin{array}{c}\text { average } \\
2000-2004\end{array}$ \\
\hline Brazil & 16.4 & 17.7 & 8.8 & 6.3 & 8.6 & 11.8 & 11.4 & 10.7 & 10.5 \\
Russian Federation &.. &.. &.. & 0.1 & 7.8 & 15.8 & 16.7 & 14.0 & 13.0 \\
India & 0.0 & 0.0 & 0.0 & 0.1 & 0.4 & 0.8 & 0.9 & 1.0 & 0.7 \\
China &.. & 0.3 & 1.3 & 2.5 & 2.6 & 2.9 & 2.6 & 2.4 & 2.7 \\
South Africa & 6.9 & 15.6 & 13.4 & 15.4 & 25.3 & 20.7 & 17.0 & 13.5 & 18.4 \\
\hline World & 5.8 & 6.6 & 8.7 & 10.0 & 19.7 & 22.7 & 24.3 & 24.0 & 22.4 \\
Developed countries & 6.2 & 7.2 & 9.6 & 11.2 & 21.5 & 25.3 & 27.3 & 27.3 & 25.0 \\
Developing countries & 4.1 & 4.1 & 4.3 & 6.1 & 13.6 & 13.5 & 13.4 & 12.7 & 13.4 \\
European Union & 6.0 & 10.4 & 11.5 & 14.5 & 37.0 & 41.0 & 43.0 & 40.9 & 40.2 \\
United States & 7.8 & 5.7 & 7.5 & 9.5 & 13.5 & 15.4 & 16.5 & 17.2 & 15.4 \\
Japan & 1.8 & 3.2 & 6.6 & 4.5 & 5.8 & 7.6 & 7.8 & 7.9 & 7.3 \\
United Kingdom & 15.0 & 22.0 & 23.2 & 26.9 & 62.4 & 63.5 & 68.7 & 64.8 & 64.1 \\
Germany & 4.6 & 8.4 & 9.0 & 10.9 & 29.0 & 35.0 & 35.0 & 30.8 & 32.6 \\
Denmark & 3.0 & 3.0 & 5.5 &.. & 46.1 & 50.1 & 48.4 & 41.1 & 47.0 \\
\hline Source: UNCTAD, World Inver.
\end{tabular}

Source: UNCTAD, World Investment Report 2005

\section{Recipients of outward FDI from BRICS}

As discussed earlier, TNCs from emerging and developing economies (ETNCs) tend to invest close to their home country and where they have acquired a certain familiarity through trade, or ethnic and cultural ties. It has been estimated that by the end of the past decade, more than a third of the FDI going to developing countries came from their peers (Economist 2005). In third wave of OFDI, though, ETNCs are increasingly venturing beyond their immediate region. Latin American and

\footnotetext{
${ }^{2}$ UNCTAD’s definition of ‘developing countries’ also includes high-income countries in the South (e.g. Singapore).
} 
Asian investments are venturing into Africa, Asian investments into Latin America and vice versa. More recently, Chinese and Indian firms have acquired high value assets in the US and EU countries (Battat \& Aykut 2005), often under considerable media attention.

In the case of Brazil, other Latin American countries as well as the U.S., are the most prominent destinations of outward FDI. Chile and Venezuela are prominent Latin American recipients. A good part of outward capital movement from Brazil appears to involve capital flows seeking shelter from taxation or undertaking currency transactions, and countries such as Bahamas, Bermuda, and the British Virgin Islands accounted for about 70\% of Brazil's total FDI outward stock in 2003. In terms of market-seeking investments, the main markets targeted are Western European countries, the United States and Mexico (UNCTAD 2004).

Russian OFDI is mainly directed towards the traditional neighbouring host countries such as Commonwealth of Independent States (CIS), Europe and CEE. At the same time OFDI in nontraditional locations such as Australia, Africa, the European Union and the United States is increasing. About half of Russian OFDI stock is believed to be in the European Union, while the CIS and the United States each accounted for about a one-fifth share (Kalotay 2003; UNCTAD 2005a).

Indian OFDI was during the period from 1975 to 1990 more concentrated in other developing countries, which may suggest that Indian firms were not yet able to compete with industrialized TNCs. Competition from TNCs within India is also likely to have been a contributing factor to outward investments. Other main motives for outward investments were to escape from a restrictive business environment in terms of government regulations, the high costs of domestic and imported inputs, and the desire to exploit the growing markets of host countries. Especially during the first wave, proximity in geography, languages, history and ethnicity had strong impact on the location decision of Indian outward investors. Singapore, Thailand, Sri Lanka and Malaysia took the lion's share of OFDI in services from India during 1975-90. During the second wave, Indian OFDI moved towards industrialized countries in terms of locations (Pradhan 2005) and where OFDI in services is concerned by the 1990s most was concentrated in developed countries such as the United Kingdom and the United States. The top 15 Indian IT software and related service companies have all invested abroad, mostly in developed countries (Hindu Business Line 2004). The most crucial destinations of Indian outward FDI to date are the U.S., which accounts for $19 \%$ of total cumulative outflows during 1996-2003 and the Russian Federation, with 18\% of the cumulative outflows. Two tax havens, Bermuda and British Virgin Islands, together account for $11 \%$ of cumulative outward FDI followed by Mauritius (9\%). A double taxation avoidance treaty between India and Mauritius appears to have encouraged Indian firms to 'round trip' investment through Mauritius and other tax haven countries to take advantage of the tax benefits enjoyed by overseas investors.

Most Chinese OFDI is directed towards other developing countries, not only in Asia but also in Africa and Latin America (UNCTAD 2005c). So far, the quest to acquire foreign mining, oil, and gas assets has dominated the buying spree. Chinese companies have acquired a wide range of assets, though often at considerable premiums, and run them successfully, particularly in emerging markets. Western markets have been more difficult to enter. Some Chinese bids to take over raw material assets and consumer goods companies have failed, partly because of opposition from Western stakeholders (McKinsey 2006). 


\section{Sectoral composition of outward FDI from BRICS}

South-South FDI flows are highly concentrated in the infrastructure and extractive sectors, mostly in the form of large M\&A and privatization deals. Between 1998 and 2003, ETNCs contributed almost USD30 billion in infrastructure projects in developing countries. Extractive sectors have attracted a large amount of ETNCs because of three factors: (1) national oil companies from the emerging economies are leading players in the market because of their exclusive access to oil reserves; (2) most of the population and economic growth is taking place in the developing world and to ensure access to additional resources and ensure their long-term supply, countries try to acquire assets in other countries; (3) some oil and gas ETNCs such as Petrobras and Petronas leverage their advanced technological capacity, such as deep-water exploration, in order to gain global presence in the sector (Battat \& Aykut 2005).

Table 9 Main outward investing industries by country

\begin{tabular}{ll}
\hline Country & Industries \\
\hline Brazil & Energy, mining, services \\
Russia & Oil, gas, metal, manufacturing and telecommunication \\
India & Pharmaceuticals, agricultural inputs, software, IT and broadcasting \\
China & Trade and services, manufacturing, resource extraction (oil, gas, minerals), IT \\
South Africa & Resource extraction and finance \\
\hline
\end{tabular}

Table 9 lists the most important outward investing industries for each of the BRICS countries. FDI in services from Brazil reflects the large investments in offshore financial centres in the Caribbean, as well as trade-related and transport services. FDI in primary activities is negligible and relatively low in manufacturing, accounting for under 3\% of total outward stock in 2003, and was concentrated in food, beverages and tobacco, petroleum and other fuel products, and metal (UNCTAD 2004). Russian resource-based enterprises in the oil, gas, and metal industries are the the most active with OFDI. However, manufacturing and telecommunication enterprises are also investing extensively abroad (UNCTAD 2005a). Half of India's OFDI in 1999-2004 was in manufacturing (especially fertilizers, pesticides and seeds, drugs and pharmaceuticals), followed by non-financial services, including IT services and business process outsourcing (UNCTAD 2005c). There has been a trend towards outward investments in more knowledge-intensive industries such as drugs and pharmaceuticals, software, and broadcasting (Pradhan 2005). A significant portion of China's OFDI value is in resource extraction activities (oil, natural gas, and minerals), dominated by state-owned enterprises. There are also growing investments in trade and services, especially, in computer-related industries and information technology (Liu et al. 2005; UNCTAD 2005c). Most of South African enterprises that have internationalized are large firms in resource and finance industries.

\section{TNCs from BRICS}

There were altogether more than 1,000 Brazilian firms that had invested abroad (TNCs) in the late 1990s. Petrobras (petroleum and natural gas), Companhia Vale de Rio Doce (mining and quarrying) and some engineering services firms and a few Brazilian banks were the first to invest in neighboring countries in the 1970s. But generally, Brazilian firms have so far been cautious in expanding abroad. Many have internationalized a significant share of their output through exports rather than through investments. This is not surprising given that outward FDI normally does not come in the early stages of a company's internationalization, even in the case of seasoned Brazilian exporters (UNCTAD 2004).

Russian OFDI is predominantly by large firms. The role of SMEs in internationalization has been limited and they tend to operate closer to home, in the CIS and CEE markets. A strategy to improve 
competitiveness of Russian oil enterprises is to undertake OFDI to internalize or control the value chain internationally (UNCTAD 2005a). Major outward investors include Lukoil (oil and gas), Gazprom (oil and gas), JSC Novoship (Shipping), Norilsk (Non-ferrous metals), Primorsk Shipping Corporation and the Far East Shipping Company (UNCTAD 2005c).

Examples of Indian companies with large outward investments are in IT (Wipro and Infosys), manufacturing (Tata), pharmaceuticals (Ranbaxy) and natural resources (ONGC-Videsh). Many Indian SMEs also are expanding abroad, e.g. Roto Pumps. Other SMEs with successful overseas ventures include B4U Multimedia International (music entertainment channels in 50 countries), Cipla Ltd. (a small drug manufacturer) and ACE Laboratories (a pharmaceutical firm) (UNCTAD 2005c).

Even though, as we saw above, recent outflows from China have been modest compared to other BRICS countries, in 2001 China provided 12 of the 50 largest TNCs from developing countries. Large Chinese OFDI projects included the China National Petroleum Corporation's joint venture with Government of Sudan to produce oil as the Greater Nile Operating Company, and the Shanghai Huayuan Group Corporation's purchase of a French textile company in Nigeria (Liu et al. 2005). Other examples are enterprises such as Haier in white goods industries and Huawei Technologies in electronics and IT activities. These enterprises have also invested in overseas R\&D activities (e.g. in India, Sweden, Singapore, U.K., U.S.). Other electronics companies have made acquisitions abroad e.g. the merger of TCL with the TV and DVD operations of Thomson in France and Lenovo's acquisition of IBM's PC division. Not just large Chinese enterprises but SMEs too are investing abroad. Many factors drive the overseas expansion of Chinese enterprises. China's government has loosened foreign-currency controls, streamlined the approval process for overseas investments, and encouraged banks to provide capital. Private equity firms, mainly from the West, are offering access to additional capital and proposing investment opportunities to Chinese business leaders. Moreover Chinese business leaders increasingly believe that international expansion is an essential stepping-stone for growth (McKinsey 2006).

Notable success stories of South African TNCs include AngloGold Ashanti (gold production), Illovo Sugar (sugar production in South Africa and in neighboring countries), Mondi (paper production) Steinhoff (furniture manufacturing) and the MTN group (cellular phone services). There are also small- and medium-sized South African enterprises investing abroad such as Spanjaard Ltd., Metorex, DPI Plastics (UNCTAD 2005c).

\section{Conclusion}

With the progress of globalization and changes in policy orthodoxy, foreign investments have become an increasingly important component in the economic strategies of firms and countries alike. Even though world investment flows are still heavily dominated by flows within the Triad, outward investments from emerging and developing economies (OFDI) has increased significantly in recent years. A deeper probing into the features of OFDI revealed recent shifts in the investment motives, modes of ownership, sectoral composition and typical destinations of OFDI; shifts sufficiently large to warrant the proposition of a new and qualitatively different 'third wave' of OFDI, different from the two previous waves depicted in the literature.

For each of the five BRICS countries we took a closer look at the historical and contemporary trends in their outward investment flows. Out of the five countries, Russia has become the largest outward investor in terms of stock, followed by Brazil and China. The table below summarises some main characteristics of OFDI from each country. 
Table 10 Summary of outward FDI from BRICS

\begin{tabular}{|c|c|c|c|c|c|}
\hline & Brazil & Russia & India & China & South Africa \\
\hline $\begin{array}{l}\text { Outward stock } 2004 \\
\text { (USD billion) }\end{array}$ & 64.4 & 81.9 & 6.6 & 38.8 & 28.8 \\
\hline - share of GDP & $10.7 \%$ & $14.0 \%$ & $1.0 \%$ & $2.4 \%$ & $13.5 \%$ \\
\hline $\begin{array}{l}\text { Average outflows } \\
2000-2004 \text { (USD } \\
\text { billion) }\end{array}$ & 2.4 & 5.9 & 1.4 & 2.4 & -0.3 \\
\hline - share of GDP & $0.42 \%$ & $1.42 \%$ & $0.19 \%$ & $0.17 \%$ & $-0.41 \%$ \\
\hline Sectors & $\begin{array}{l}\text { Energy, mining, } \\
\text { services }\end{array}$ & $\begin{array}{l}\text { Resource extraction } \\
\text { (oil, gas, metal), } \\
\text { manufacturing, } \\
\text { telecom }\end{array}$ & $\begin{array}{c}\text { Pharmaceuticals, } \\
\text { agricultural inputs } \\
\text { manufacturing, } \\
\text { software, IT services, } \\
\text { broadcasting }\end{array}$ & $\begin{array}{c}\text { Trade, services, } \\
\text { manufacturing, } \\
\text { resource extraction } \\
\text { (oil, gas, minerals), } \\
\text { IT }\end{array}$ & $\begin{array}{c}\text { Resource } \\
\text { extraction, finance }\end{array}$ \\
\hline Recipients & $\begin{array}{l}\text { Latin America, tax } \\
\text { havens (Bermuda, } \\
\text { Cayman Islands, } \\
\text {...), US, UK, } \\
\text { Portugal, } \\
\text { Netherlands }\end{array}$ & $\begin{array}{l}\text { European Union, } \\
\text { CIS, US, CEE }\end{array}$ & $\begin{array}{l}\text { US, Russia, tax } \\
\text { havens (Bermuda, } \\
\text {..), Southeast Asia, } \\
\text { Sri Lanka, UK }\end{array}$ & $\begin{array}{l}\text { HK, US, Japan, } \\
\text { Australia, Germany }\end{array}$ & $\begin{array}{l}\text { Neighboring } \\
\text { countries }\end{array}$ \\
\hline Example TNCs & $\begin{array}{c}\text { Petrobras, } \\
\text { Odebrecht, Embraer }\end{array}$ & $\begin{array}{l}\text { Lukoil JSC, Norilsk } \\
\text { Nickel, Novoship Co. }\end{array}$ & $\begin{array}{l}\text { NIIT Ltd., Usha } \\
\text { Martin, Ranbaxy }\end{array}$ & $\begin{array}{c}\text { China Ocean } \\
\text { Shipping Grp.; China } \\
\text { National Offshore Oil } \\
\text { Corp.; China } \\
\text { National Cereals, } \\
\text { Oils \& Foodstuffs } \\
\text { Corp., Lenovo }\end{array}$ & $\begin{array}{l}\text { Illovo Sugar, MTN, } \\
\text { AngloGold Ltd. }\end{array}$ \\
\hline Notes & $\begin{array}{l}\text { TNCs tend to rely } \\
\text { more on exports } \\
\text { than FDI }\end{array}$ & $\begin{array}{l}\text { Outflows repeatedly } \\
\text { higher than inflows }\end{array}$ & & & $\begin{array}{c}\text { Single largest } \\
\text { source of OFDI from } \\
\text { Africa }\end{array}$ \\
\hline
\end{tabular}

Source: UNCTAD 2004; UNCTAD 2005a; Pradhan 2005; Deng 2004; Spicer 2006; UNCTAD 2005c, World Bank and UN statistics

\section{References}

Andreff, V. (2003), 'The newly emerging TNCs from economies in transition: a comparison with Third World outward FDI', Transnational Corporations, Vol.12, No.2 (August).

Agarwal, J.P. (1985), Pros and Cons of Third World Multinationals: A Case Study of India, Tübingen: J.C.B. Mohr and Paul Siebeck.

Aitken, B.G.H. and A. Harrison (1997), 'Spillovers, foreign investment, and export behavior', Journal of International Economics, 43, pp. 103-132.

Aykut D., D. Ratha (2004)., 'South-South FDI Flows: how big are they?' Transnational Corporations, Vol.13, No.1 (April).

Balasubramanyam, V.N., M. Salisu and D. Sapsford (1996), 'Foreign direct investment and growth in EP and IS countries', Economic Journal, 106 (1), pp. 92-105.

Battat J., D. Aykut (2005), 'Southern Multinationals, A Growing Phenomenon', Foreign Investment Advisory Services (FIAS), October.

Bell, M. and A. Marin (2004), 'Where do FDI-related Technology Spillovers Come From in Emerging Economies? An exploration in Argentina in the 1990s', The European Journal of Development Research, Vol. 16, No. 3, Autumn, pp. 645-677.

Benito, G. and R. Narula (eds.) (2007), Multinationals on the Periphery, PalgraveMacmillan.

Blomström, M., R. Lipsey and M. Zejan (1996), 'Is fixed investment the key to economic growth?', Quarterly Journal of Economics, 111 (1), pp. 269-276.

Borensztein, E., J. Gregorio and J. Lee (1998), 'How does foreign direct investment affect economic growth’, Journal of International Economics, 45 (1), pp. 115-135.

Bulatov, A. (1998), 'Russian Direct Investment Abroad: Main Motives in the Post-Soviet Period', Transnational Corporations, Vol. 7, No. 1. 
Cai, K.G. (1999), 'Outward foreign direct investment: A novel dimension of China's integration into the regional and global economy', The China Quarterly, 160: 856-880.

Chakraborty, C. and P. Basu (2002), 'Foreign direct investment and growth in India: A cointegration approach’, Applied Economics, 34, pp. 1061-1074.

Chudnovsky, D. and A. López (2000), 'A third wave of FDI from developing countries: Latin American TNCs in the 1990s', Transnational Corporations, Vol.9, No.2: 31-75.

Cohen, W. and D. Levinthal (1990), Absorptive capacity: A new perspective on learning and innovation, Administrative Science Quarterly, Vol. 24, pp. 128-152.

De Mello Jr., L.R. (1997), 'Foreign direct investment in developing countries and growth: A selective survey’, Journal of Development Studies, 34, pp. 1-34.

Deng P. (2004), 'Outward investment by Chinese MNCs: motivations and implications', Business Horizons, 3/47.

Doner, R.F. (1991), 'Approaches to the politics of economic growth in Southeast Asia', Journal of Asian Studies, Vol. 50, No. 4.

Dunning, J.H. (1988), Explaining International Production, London: Harper and Collins.

Durham, J.B. (2004), 'Absorptive capacity and the effects of foreign direct investment and equity foreign portfolio investment on economic growth', European Economic Review, 48 (2), pp. 285306.

Dunning J.H., R. van Hoesel and R. Narula (1996), 'Explaining the “new” wave of outward FDI from developing countries: The case of Taiwan and Korea', Research Memoranda 009, Maastricht Economic Research Institute on Innovation and Technology.

Dunning, J.H., R. van Hoesel and R. Narula (1998), 'Third World Multinationals Revisited: New Developments and Theoretical Implications’ in J.H. Dunning (ed), Globalization, Trade and Foreign Direct Investment, Pergamon.

Economist, The (2005), 'Globalization with a third-world face', 7 April.

Girma, S., D. Greenaway and K. Wakelin (2001), 'Who benefits from foreign direct investment in the UK?', Scottish Journal of Political Economy, 48 (2), pp. 119-133.

Goldstein, A. and T.M. Shaw (2007), Multinational Companies from Emerging Economies: Composition, Conceptualization and Direction in the Global Economy, PalgraveMacmillan.

Hindu Business Line, The (2004), 'FDI outflow rises as Indian cos clinch more buys overseas: UNCTAD', 23 October, www.thehindubusinessline.com

Hirschman, A. D. (1958), The Strategy of Economic Development, New Haven, Conn.: Yale University Press.

Huang Jr., T. (2004), ‘Spillovers from FDI in China’, Contemporary Economic Policy, 22 pp. 1325.

JIBS (2007), International Expansion of Emerging Market Businesses, Journal of International Business Studies, Special Issue, 38(4).

JIM (forthcoming), Journal of International Management, special issue on 'Third-World Multinationals and Global Competition'.

Keller, W. (1996), 'Absorptive capacity: on the creation and acquisition of technology in development', Journal of Development Economics, 49(1), pp. 199-227.

Kalotay, K. (2003), 'Outward Foreign Direct Investment From Economies in Transition in a Global Context', Journal for East European Management Studies, Vol. 8, No. 1, pp. 6-24.

Kokko, A. (1994), 'Technology, market characteristics and spillovers', Journal of Development Economics, 43, pp. 279-293.

Lall, S. (1983), The New Multinationals: The Spread of Third World Enterprises, New York: Wiley.

Lall, S. (1995), 'Industrial strategy and policies on foreign direct investment in East Asia', Transnational Corporations, Vol. 4, No. 3 (December).

Lecraw, D.J. (1977), 'Direct Investment by Firms from Less Developed Countries', Oxford Economic Papers, pp. 442-457. 
Lecraw, D.J. (1993), 'Outward Direct Investment by Indonesian Firms: Motivation and Effects', Journal of International Business Studies, 24(3): 589-600.

Lipsey, R.E. (2005), 'UNCTAD, Expert Meeting on Capacity building in the Area of FDI: Data Compilation and Policy Formulation in Developing Countries', 12-14 December.

Liu, X., T. Buck, and C. Shu (2005), 'Chinese economic development', International Business Review, Vol.14, Issue 1, February, pp. 97-115

McKinsey (2006), 'Helping China’s companies master global M\&A', The McKinsey Quarterly, August

Moran, T.H. (1978), 'Multinational corporations and dependency: a dialogue for dependentistas and non-dependentistas', International Organization, 32 (Winter), 79-100.

Mortimore, M. (2004) 'The impact of TNC strategies on development in Latin America and the Caribbean’, in D. W. Te Velde (ed.), Foreign Direct Investment and Development: selected experiences and policy implications, London: Overseas Development Institute.

Olofsdotter, K. (1998), 'Foreign direct investment, country capabilities and economic growth', Weltwitschaftliches Archive, 134 (3), pp. 534-547

Pradhan J.P. (2005), 'Outward foreign direct investment from India: Recent Trends and Patterns', Working paper No.153, Gujarat Institute of Development Research, February

Ram, R. and K.H. Zhang (2002), 'Foreign direct investment and economic growth: Evidence from cross-country data for the 1990s', Economic Development and Cultural Change, 51, pp. 205215.

Sauvant, K.P. (2005), 'New Sources of FDI: The BRICs', Journal of World Investment \& Trade, Vol. 6, No. 5, October, pp. 639-709.

Singer, H. (1975), The Strategy of International Development, New York: International Arts and Science Press.

Sinha J. (2005), ‘Global Champions from emerging markets’, The McKinsey Quarterly 2005, No. 2

Sjöholm, F. (1999), 'Technology gap, competition and spillovers from direct investment: Evidence from establishment Data', Journal of Development Studies, 36 (1), pp. 53-73.

Spicer, M. (2006), 'South African Multinationals and Economic Development in Africa', Presentation to conference on emerging multinationals, OECD Conference Centre, Paris, 27 March.

Taki, S. (2005), 'Productivity spillovers and characteristics of foreign multinational plants in Indonesian manufacturing 1990-1995', Journal of Development Economics, 76, pp. 521-542.

TC forthcoming, Transnational Corporations, special issue on outward investment from the South, planned for 2008.

Tolentino, P.E. (1993), Technological Innovation and Third World Multinationals, London \& New York: Routledge.

UNCTAD (1999), Foreign Direct Investment and the Challenge of Development, World Investment Report 1999, Geneva: United Nations.

UNCTAD (2004), Outward FDI from Brazil: poised to take off?, 7 December.

UNCTAD (2005a), Case study on outward foreign direct investment by Russian enterprises, 8 November.

UNCTAD (2005b), 'Firms in developing countries rapidly expanding foreign investment transnational activities', press release, 30 May.

UNCTAD (2005c), 'Internationalization of developing-country enterprises through outward foreign direct investment', 2 November

UNCTAD (2006), FDI from Developing and Transition Economies: Implications for Development, World Investment Report 2006, Geneva: United Nations.

van Hoesel, R. (1999), 'New Multinational Enterprises from Korea and Taiwan: Beyond Export-led Growth', New York: Routledge.

Wade, R. (1995), 'Lessons from East Asia', in Stuart Corbridge (ed.), Development Studies: A Reader, London: Edward Arnold. 
Wells, L.T. (1983), Third World Multinationals: The Rise of Foreign Investment from Developing Countries, Cambridge, MA: MIT Press.

Yeung, H. (ed.) (2000), The Globalization of Business Firms from Emerging Economies, Cheltenham: Edward Elgar.

Zhang, K.H. (2001), 'Does foreign direct investment promote economic growth? Evidence from East Asia and Latin America’, Contemporary Economic Policy, 19(2), pp. 175-185. 